Research article

\title{
Morpho-anatomical description of Lygodium hazaricum Haq a new contribution to the fern flora of Pakistan
}

\author{
Faizul Haq \\ Department of Botany, Government Degree College, Battagram, Khyber Pakhtunkhwa, Pakistan \\ *Corresponding Author: faizulhaq80@yahoo.com \\ [Accepted: 29 August 2017]

\begin{abstract}
Lygodium hazaricum a climbing fern was collected from Nandiar valley western Himalayas during 2016. The rhizome is widely creeping, dichotomously branched and densely clothed with dark brown hairs. The epidermal layer of rhizome is covered with dark brown hairs, which is sheeting at base and acute at tip. Roots arise opposite to fronds and root branches are bulbous. Rachis is with solid oval protostele. The cells of phloem are smaller than xylem cells. The sporangia are $600 \mu \mathrm{m}$ long and $500 \mu \mathrm{m}$ wide, globular in cross section. Sporangium is very short stalked and placed horizontally. The mature sporangium has upto 256 spores. Spores are subtriangular. Sporangium also contains few red spores. L. hazaricum is used for the treatment of diarrhea, dysentery and hepatitis. It is a new contribution to the fern flora of Pakistan.

Keywords: L. hazaricum Haq - Morphology - Anatomy - Sporangia - Spore - Nandiar valley.
\end{abstract}

[Cite as: Haq F (2017) Morpho-anatomical description of Lygodium hazaricum. Haq a new contribution to the fern flora of Pakistan. Tropical Plant Research 4(2): 358-362]

\section{INTRODUCTION}

The genus Lygodium Sw. is placed in family Lygodiaceae comprises 45 species throughout the world. Previously it was placed in family Schizaeceae (Murtaza et al. 2004). The plants of Lygodiaceae family are terrestrial (Lott et al. 2003). Stems slender; branched, fronds several meters, alternately pinnate, climbing by means of a twining rachis; primary blade divisions (pinnae) pseudo dichotomously forking with a dormant apical bud in axils; pinnules entire to palmately or 1- or 2-pinnate or more divided; fertile and sterile pinnae similar or fertile pinnae greatly contracted; veins free or anastomosing; sori on lobes of ultimate segments; sporangia abaxial, solitary, 1 per sorus, each sporangium covered by an antrorse indusium-like subtending flange; spores 128-256 per sporangium, tetrahedral and trilete; gametophytes green, cordate, terrestrial. $x=29$, 30 (Zhang \& Hanks 2013). The species of Lygodium occur from tropical to temperate region of the world (Schmitz et al. 1997, Pemberton 1998, Pemberton \& Ferriter 1998, Murtaza et al. 2004).

In Pakistan there is no detailed study of fern flora. Stewart (1957) and Sheikh (1962) described certain fern species from Kaghan Valley. In Pakistan only Lygodium japonicum (Thunb.) Sw. has been reported from Kashmir and Mansehra districts (Stewart 1957, Sheikh 1962, Murtaza et al. 2004).The morphology, anatomy and palynology of few ferns have been investigated (Murtaza et al. 2004, 2008).The current study is an effort to add some information about the Lygodium hazaricum Haq collected from Nandiar valley district Battagram.

\section{MATERIALS AND METHODS}

The specimens of Lygodium hazaricum Haq were collected from Nandiar valley district Battagram during 2016. The material was preserved in acetic alcohol (1:3) till further use. The plant morphology was studied with naked eye and USB digital microscope. For anatomical studies, the transverse sections of the, root, rhizome and rachis were prepared. The clearing of leaflets/fronds was made according to the techniques used by Bhutta \& Sadiq (1987). The fronds were washed with distilled water. The sporangia were detached from the fertile fronds with the help of needle under binocular microscope. For spore investigations, the sori were crushed with glass rod and passed through $4 \mathrm{~cm}$ diameter funnel placed in a centrifuge tube and plucked with loosely placed glass wool. The sieved spores were treated with $5 \% \mathrm{KOH}$ solution to remove the oils and humic acid. The spores were chlorinated as suggested by Bhutta \& Sadiq (1987) and mounted in $2 \%$ glycerin jelly already stained with 
$2 \%$ safranin (Erdtman \& Sorsa 1971). The specimen were compared with the available literature (Stewart 1957, Sheikh 1962, Murtaza et al. 2004, 2008, Zhang \& Hanks 2013). The specimens were deposited in the department of Botany, government degree college Battagram for future reference.

\section{RESULTS AND DISCUSSION}
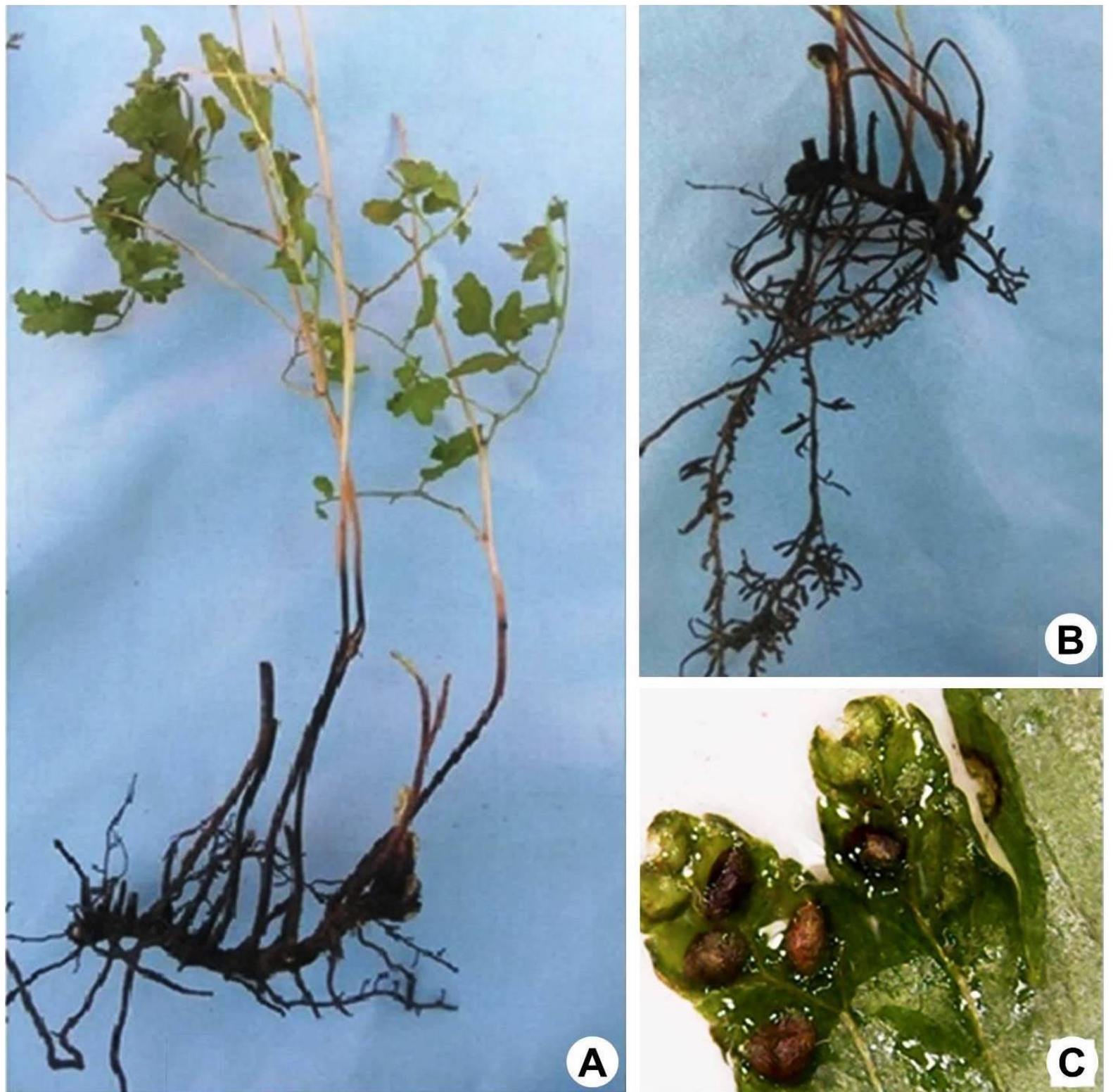

Figure 1. Morphology of Lygodium hazaricum Haq: A, Full plant; B, Rhizome and rhizoid; C, Sporangia on leaf margin.

\section{Morphology}

Dark brown rhizome, 3-6 mm in diameter, widely creeping, dichotomously branched, densely clothed with dark brown hairs. Roots arises opposite to fronds 3-8 mm apart, root branches bulbous and flattened 2-5 mm apart, 6-12 mm long. Juvenile fronds erect, 3-10 mm apart, first branching an unequal dichotomy, main branches of large fronds bipinnate, deltoid in outline, with palmatisect pinnae, pinna margins doubly serrate. Rachis of climbing fronds 1-2 mm in diameter, upto 60 feet, slightly oval in outline, glabrous, hairs present on flattened adaxial surface between wings; primary rachis branches 3-11 mm, dormant apex covered with pale hairs; secondary branches of fronds on young or stunted plants pinnate, on well-grown fronds bipinnate or tripinnate, deltoid in outline, commonly $c a .14 \mathrm{~cm}$ long and wide, rachises densely shortly hairy on adaxial surface and with fewer longer hairs elsewhere; sterile tertiary pinnae of lower rachis branches., palmate with 37 lobes, middle lobe much longer than lateral lobes, tertiary pinnae higher up frond 3-lobed with an elongate middle lobe or pinnate with small oblique and often lobed quaternary pinnae and a usually deltoid-pinnatisect 
terminal pinna $c a .3 \mathrm{~cm}$, margins acutely biserrate, apex obtuse or subacute; stalks of pinnae up to $3 \mathrm{~mm}$, never articulate or thickened at apex; costae with long scattered hairs, veins and surfaces usually glabrous but sometimes shortly hairy; fertile secondary branches tripinnate, pinnae smaller than sterile pinnae, sorophores 2$12 \mathrm{~mm}$; indusia glabrous or with few hairs if lamina hairy (Fig. 1). Similar morphological characters were also presented by Haq (2015) from Battagram district.
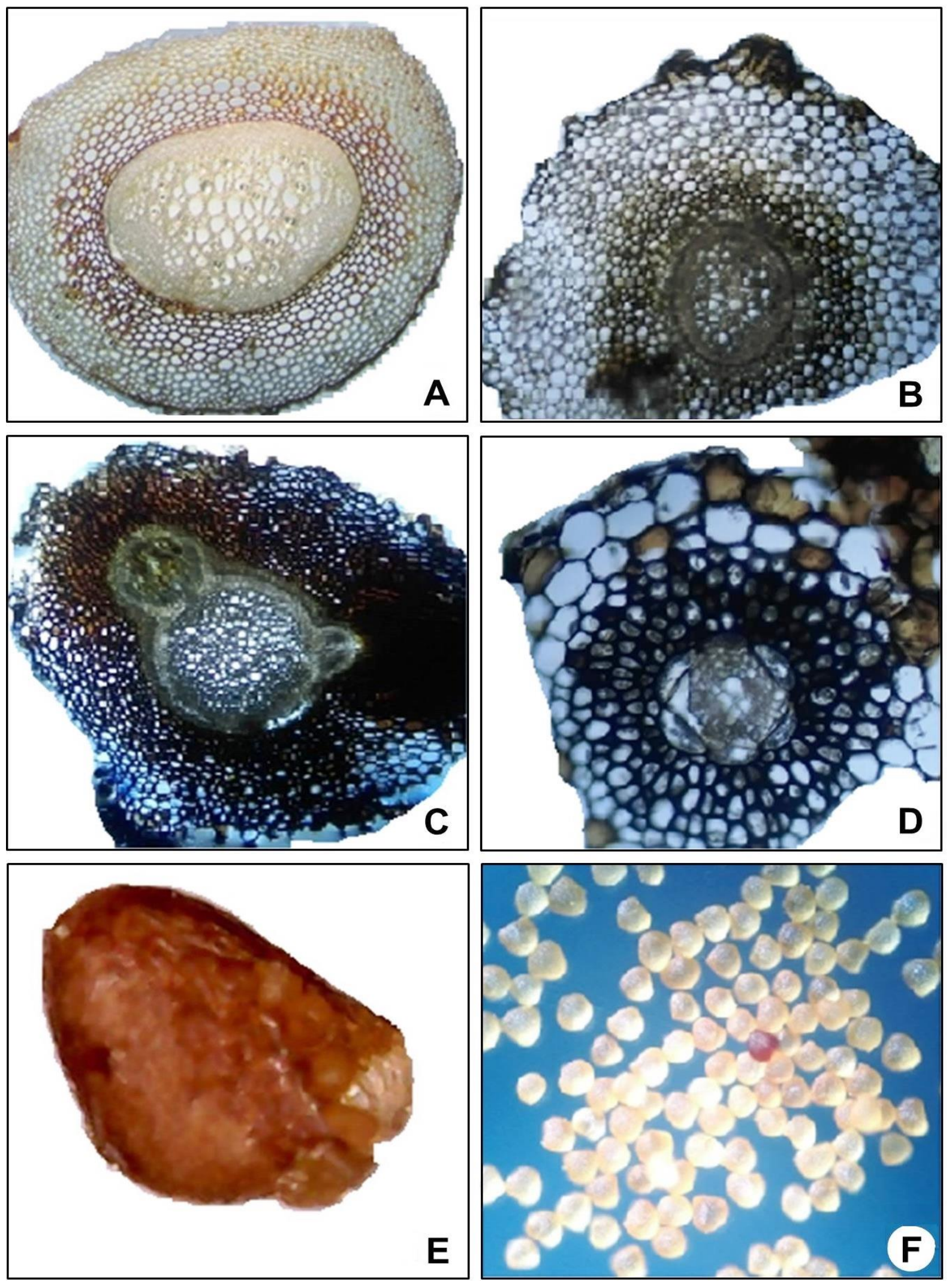

Figure 2. Anatomy of Lygodium hazaricum Haq: A, Rachis; B-C, Rhizome; D, Root; E, Sporangium; F, Spores. www.tropicalplantresearch.com 
Anatomy of rachis

The rachis is slightly oval. The cutinized epidermis was single layered, slightly hairy in young fronds. The cells of the epidermis were broader than longer. Hypodermis consisted of 3-6 layers. Protostele, solid, almost oval, covered by endodermis and pericycle. The cells of the phloem were smaller than xylem cells. The phloem is protruded into bays formed by three angled protoxylum and protostele. The cortical region is parenchymatous (Fig. 2A). Murtaza et al. (2004) also reported the anatomical structure of L. japonicum.

\section{Anatomy of rhizome}

The rhizome was dark brown, almost circular in outline. The epidermal layer was covered with dark brown hairs, hair base was sheeting and with acute tip. Below epidermis there was a cortical region. The cortical layers were differentiated with outer whitish parenchymatous tissue and inner brown collenchymatous tissue. Inner to the cortex was distinct endodermis followed by 1-3 pericycle layers. Protostele was solid, almost rounded. The cells of the phloem were smaller than xylem cells. The traces of rachis and root were almost opposite (Fig. $2 \mathrm{~B} \& \mathrm{C})$.

\section{Anatomy of root}

The root was rounded and dark brown in color. The outer most layer was damaged epidermis. The cortex was differentiated into outer larger cells of 2-3 layers and inner smaller cells of brown in color of 5-7 layers. Inner to the cortex was endodermis of usually 6 cells with unequal size. It was followed by a single layer pericycle. The xylem was surrounded by phloem. The xylem cells are larger than phloem cells (Fig. 2D).

Sporangium

The sporangia was $600 \mu \mathrm{m}$ long and $500 \mu \mathrm{m}$ wide, globular in cross section. Sporangia was seated near each vein dichotomy and was protected by the curled margin (Fig. 2E). Sporangium was very short stalked and was placed horizontally. The annulus was clearly shown and having 65um thickness in cross section (Fig. 2E). The mature sporangium has upto 256 spores. The sporangium morphology of similar fern Schizaea dichotoma was also presented by Murtaza et al. (2008).

Spores

Spores were subtriangular, 60-90 $\mu \mathrm{m}$ equatorial diameter, isosporous, coatour anisomorphic, trilete, laesurea almost to the length of the spore radius, commissure open, extremities of arm slightly arculate, proximal surface slightly reticulate, distal surface heavily warty at equatorial line and variable in dimensions. At certain points they are oriented in reticulate pattern. Outer layer was thick exine and inner was thin intine. Few red spores were also seen in the same sporangium (Fig. 2F). Lott et al. (2003) also reported the reproductive biology of Lygodium microphyllum (Cav.) R. Br. and L. japonicum and reported similar result.

\section{Uses of the plant}

The powder of whole plant is used for the treatment of diarrhea, dysentery and hepatitis. Similar results were also presented by Haq et al. (2011) from same area.

\section{CONCLUSION}

Lygodium hazaricum Haq is a premative fern having protostele stem, dichotomous brancheed venation of open type as these character are quite primative. I concluded from morphology, anatomy of rachis, rhizome, root, sporangia and spore are the character that it was differentiated as a new species to the fern flora of Pakistan. It is recommended that a complete biochemical investigation and genotype should be studied for clarifification of its position in classification.

\section{ACKNOWLEDGEMENTS}

The author is thankful to the Head of Department and all other staff of Department of Botany, Government Degree College, Battagram, Khyber Pakhtunkhwa, Pakistan for their valuable support during the study.

\section{REFERENCES}

Bhutta AA \& Sadiq A (1987) A modified technique to study the xylem of plants or plant organs. Bulletin of the Palaeobotany and Palynology Club of Pakistan 1: 43-45.

Erdtman G \& Sorsa P (1971) Pollen and spore morphology/plant taxonomy. Almqvist and Wiksells, Boktryckeri Aktiebolag Upsala, 302 p. 
Haq F (2015) Phytosociological attributes of different vegetational zones of Nandiar Khuwar catchment area, Ph.D. Thesis. Department of Botany, Hazara University, Pakistan.

Haq F, Ahmad H \& Alam M (2011) Traditional uses of medicinal plants of Nandiar Khuwarr catchment (District Battagram), Pakistan. Journal of Medicinal Plants Research 5(1): 39-48.

Lott MS, Volin JC, Pemberton RW \& Ustin DFA (2003) The reproductive biology of the invasive ferns Lygodium microphyllum and L. japonicum (Schizaeaceae): implications for invasive potential1. American Journal of Botany 90(8): 1144-1152.

Murtaza G, Asghar R, Majid SA \& Malik ZH (2008) Morphopalynological and anatomical studies on fan fern Schizaea dichotoma (L.) Smith from Neelum valley, Azad Kashmir. Pakistan Journal of Botany 40(1): 5963.

Murtaza G, Majid SA \& Asghar R (2004) Morpho-palynological studies on the Climbing Fern Lygodium japonicum. Asian Journal of Plant Sciences 3: 728-730.

Pemberton R \& Ferriter A (1998) Old World climbing fern (Lygodium microphyllum), a dangerous invasive weed in Florida. American Fern Journal 88: 165-175.

Pemberton R (1998) The potential of biological control to manage Old World climbing fern (Lygodium microphyllum), an invasive weed in Florida. American Fern Journal 88: 176-182.

Schmitz D, Simberloff D, Hoffstetter R, Haller W \& Sutton D (1997) The ecological impact of non-indigenous plants. In: Simberloff D, Schmitz D \& Brown T (eds) Strangers in paradise. Island Press, Washington D.C., USA, pp. 39-74.

Sheikh AH (1962) Ferns of Kaghan valley. Pakistan Journal of Scientific Research 14: 195-209.

Stewart RR (1957) The ferns and fern allies of West Pakistan and Kashmir. Biologia 3(2): 133-164.

Zhang XC \& Hanks JG (2013) Lygodiaceae. In: Wu ZY, Raven PH \& Hong DY (eds) Flora of China, Vol. 2-3 (Pteridophytes). Science Press, Beijing \& Missouri Botanical Garden Press, St. Louis, pp. 118-121. 